\title{
EDITORIAL
}

\section{Sistema Nacional de Saúde}

Desde de 18 oe julho do corrente ano estamos com a nova Lei que dispõe sobre o Sistema Nacional de Saúde, publicada no Diário Oficial da República desse dia.

$A$ Lei, citada, tem apenas oito artigos. $O$ artigo $10^{\circ}$ tomou a primeira página inteira do Diário Ofícial. O que é esse Sistema? $E$ constituído pelo "complexo de serviços, do setor público e do setor privado, voltados para as ações de interesse da saúde".

Aos poucos, nestes próximos anos, é de esperar que sejam organizados e disciplinados, sob o princípio sistêmico e integrado, os setores desse complexo aqui referido. Para nós, que exercemos profissões e ocupações de saúde, é fundamental termos essa esperança. Isso se declara pelo fato de os serviços de enfermagem serem inadequados no presente; porém temos aspirações quanto ao futuro.

Bem sabemos que as causas e efeitos que se acham associados com essa inadequação estão em interação. E por este último aspecto, precisamente, que a perspectiva sistêmica, integrada, para a saúde deve ter boa influência na resolução dos grandes problemas que têm dificultado a prestação da assistência de enfermagem.

Uma das diretrizes importantes do Sistema Nacional de Saúde é a que incumbe ao Estado dar ajuda aos Municípios para que estes façam funcionar serviços básicos de saúde para a população local, especialmente prontosocorro e vigilância epidemológica. Já foi referido que a expansão dos programas de abastecimento d'água e esgotos compete ao Ministério do Interior, que atende a prioridades estabelecidas de modo interrelacionado.

Ao relatar em poucas palavras este magno assunto, cabe aqui referir que a existência do Conselho de Desenvolvimento Social, de que são responsá- 
veis o Presidente da República, os Ministros do Planejamento e Coordenação Geral, da Fazenda, Previdência e Assistência Social, da Saúde e do Trabalho, e ainda os da Educação e Cultura, facilita a aprovação de planos integrados.

Se o País não estivesse no bom nível atual de seu desenvolvimento, poderíamos admitir que seria esta uma daquelas leis feitas sem esperança de serem cumpridas. No que diz respeito às profissões e ocupações de enfermagem, pode-se ter esperança de que deem seu concurso específico, que é essencial para que o Sistema Nacional de Saúde surja cada vez mais forte e operante no País. (H. G. D.) 